\title{
Formy i metody ksztalcenia w zakresie przedsiębiorczości w szkole podstawowej
}

DOI: 10.47050/65591760.156-166

Anna Śliwińska

W artykule podjęto problematykę kształtowania postaw przedsiębiorczych w szkole podstawowej w kontekście obowiązującej podstawy programowej. Zwrócono szczególną uwagę na kształtowanie kluczowych kompetencji i konieczność stwarzania sytuacji dydaktycznych, które temu sprzyjają. Wykazano zależność między formułowaniem celów a ocenianiem postępów uczniów. Na tym tle określono miejsce przedsiębiorczości we współczesnej szkole.

\section{Słowa kluczowe:}

przedsiębiorczość

kreatywność

innowacyjność

podstawa programowa

kluczowe umiejętności 


\section{Forms and methods of education in the field of developing entrepreneurial competences}

DOI: 10.47050/65591760.156-166

Anna Śliwińska

The article discusses the problem of shaping entrepreneurial attitudes in primary school in the context of the current core curriculum. Particular attention is paid to shaping key competences and the necessity to create teaching situations that support them. The relationship between formulating goals and assessing students' progress was demonstrated clearly in the article. Against this background, the place of entrepreneurship in a modern school was defined.

\section{Keywords:}

entrepreneurship

creativity

innovation

core curriculum

key skills 


\section{Wstęp}

W 2012 r. powstał raport ${ }^{1}$ dotyczący rozwijania kompetencji kluczowych w szkołach Europy. Wynika z niego, że wszystkie europejskie kraje zwiększyły rolę tych kompetencji w programach nauczania, ale nie w równomierny sposób. Okazało się, że główny nacisk został położony na rozwijanie umiejętności czytania i pisania, posługiwania się językiem obcym oraz na matematykę i nauki ścisłe. Niestety, umiejętności, które wydają się niezwykle istotne z punktu widzenia współczesnego pracodawcy, czyli kompetencje cyfrowe, społeczne, a także przedsiębiorczość, znalazły się na drugim planie. Podstawa programowa ${ }^{2}$ wprowadzona w 2017 r. kładzie jednak duży nacisk na kształcenie tych kompetencji.

\section{Cele ksztalcenia}

Zadaniem szkoły na każdym etapie kształcenia jest przygotowanie uczniów do dorosłego życia - do planowania i realizacji zamierzeń, do tego, by potrafili zamieniać zamiary w czyny, by umieli powiedzieć "mogę", „potrafię". Kluczowe na początku pracy z uczniami wydaje się uświadomienie im celów, ponieważ to motywuje do uczenia się i daje poczucie sensownie spędzonego czasu w szkole. Poprawne sformułowanie celów nauczania pomaga również nauczycielowi w przygotowaniu spójnej lekcji, w nastawieniu się na konkretne działania. Twórcy i propagatorzy oceniania kształtującego sugerują wręcz, by nie tylko uzgodnić z uczniami cele lekcji (oczywiście w dostosowanym do nich języku, czyli w języku ucznia), lecz także zapisać je w widocznym miejscu lub wkleić do zeszytu. W edukacji wczesnoszkolnej często pojawiają się w klasach wypisane cele, które przyświecają realizacji programu w danym miesiącu/tygodniu/dniu. Twórcy oceniania kształtującego (zob. Moss, Brookhart 2014) podkreślają, że właściwie sformułowane

1. Komisja Europejska/EACEA/Eurydice (2012), Developing Key Competences at School in Europe: Challenges and Opportunities for Policy (Rozwijanie kompetencji kluczowych w szkołach w Europie. Wyzwania i możliwości tworzenia polityki edukacyjnej) Raport Eurydice, Luksemburg: Urząd Publikacji Unii Europejskiej.

2. Rozporządzenie Ministra Edukacji Narodowej z dnia 14 lutego 2017 r. w sprawie podstawy programowej wychowania przedszkolnego oraz podstawy programowej kształcenia ogólnego dla szkoły podstawowej, w tym dla uczniów z niepełnosprawnością intelektualną w stopniu umiarkowanym lub znacznym, kształcenia ogólnego dla branżowej szkoły I stopnia, kształcenia ogólnego dla szkoły specjalnej przysposabiającej do pracy oraz kształcenia ogólnego dla szkoły policealnej. 
cele przekładają się na jasne kryteria oceny, czyli dowody, iż cel został osiągnięty (Sterna 2015).

Celem szkoły powinno być kształtowanie umiejętności i postaw kreatywnych, przedsiębiorczych i innowacyjnych, a w szczególności:

$\rightarrow$ pracy zespołowej,

$\rightarrow$ generowania pomysłów,

$\rightarrow$ rozpoznawania i rozwiązywania konfliktów,

$\rightarrow$ wykorzystywania technologii informacyjno-komputerowych,

$\rightarrow$ gromadzenia i selekcji materiału,

$\rightarrow$ prezentacji,

$\rightarrow$ planowania i realizowania przedsięwzięć uczniowskich.

Cele te spójne są z celami kształcenia ogólnego, umiejętnościami, które szkoła ma rozwijać, oraz zalecanymi warunkami i sposobami realizacji wymagań zawartymi w podstawie programowej.

Tabela 1. Kształtowanie umiejętności i postaw przedsiębiorczych

\begin{tabular}{|c|c|}
\hline KLUCZOWE ZAGADNIENIA & KSZTAŁTOWANE UMIEJĘTNOŚCI UCZNIÓW \\
\hline współpraca w grupie & $\begin{array}{l}\rightarrow \text { określają swoje miejsce w grupie } \\
\rightarrow \text { rozpoznają role w grupie i związane z nimi oczekiwania } \\
\rightarrow \text { nazywają i rozpoznają cechy lidera } \\
\rightarrow \text { omawiają zadania lidera } \\
\rightarrow \text { wskazują trudności związane z pełnieniem funkcji lidera } \\
\rightarrow \text { nazywają zachowania, które ułatwiają porozumiewanie się } \\
\text { i utrudniają współpracę } \\
\rightarrow \text { wymieniają korzyści wynikające ze współpracy }\end{array}$ \\
\hline generowanie pomysłów & $\begin{array}{l}\rightarrow \text { szukają różnorodnych rozwiązań problemu } \\
\rightarrow \text { oceniają pomysły własne i innych oraz na ich temat dyskutują } \\
\rightarrow \text { wskazują problemy związane z poszukiwaniem pomysłów } \\
\rightarrow \text { szukają argumentów, by poprzeć swoje stanowisko } \\
\rightarrow \text { stosują zasady współpracy w grupie }\end{array}$ \\
\hline $\begin{array}{l}\text { rozpoznawanie } \\
\text { i rozwiązywanie konfliktów }\end{array}$ & $\begin{array}{l}\rightarrow \text { rozważają różne możliwości rozwiązania problemu } \\
\rightarrow \text { gromadzą argumenty na poparcie własnego stanowiska } \\
\rightarrow \text { negocjują warunki } \\
\rightarrow \text { prezentują własne stanowisko w sprawie } \\
\rightarrow \text { wyjaśniają na konkretnych przykładach zasady współżycia mię- } \\
\text { dzy ludźmi, ze szczególnym zwróceniem uwagi na odpowiedzialność } \\
\text { i zaufanie } \\
\rightarrow \text { wspólnie rozwiązują problem }\end{array}$ \\
\hline $\begin{array}{l}\text { wykorzystanie technologii } \\
\text { informacyjno-komputerowej }\end{array}$ & $\begin{array}{l}\rightarrow \text { poszukują informacji, wykorzystując technologię informacyjną } \\
\rightarrow \text { tworzą dokumenty, wykorzystując technologię informacyjną }\end{array}$ \\
\hline
\end{tabular}




\begin{tabular}{|c|c|}
\hline KLUCZOWE ZAGADNIENIA & KSZTAŁTOWANE UMIEJĘTNOŚCI UCZNIÓW \\
\hline $\begin{array}{l}\text { gromadzenie i selekcja } \\
\text { materiału }\end{array}$ & $\begin{array}{l}\rightarrow \text { wykorzystują zdobyte informacje przy podejmowaniu decyzji } \\
\rightarrow \text { weryfikują i wykorzystują wiedzę z różnych dziedzin nauki, by zna- } \\
\text { leźć rozwiązanie } \\
\rightarrow \text { układają zdobyte informacje zgodnie z hierarchią ważności } \\
\rightarrow \text { oceniają zgromadzone materiały pod kątem zgodności z tematem }\end{array}$ \\
\hline prezentacja & $\begin{array}{l}\rightarrow \text { prezentują własne dokonania } \\
\rightarrow \text { wymieniają elementy ułatwiające i utrudniające odbiór prezentacji } \\
\rightarrow \text { oceniają prezentację } \\
\rightarrow \text { przygotowują materiały wizualizujące } \\
\rightarrow \text { formułują zasady dobrej prezentacji }\end{array}$ \\
\hline $\begin{array}{l}\text { planowanie i realizowanie } \\
\text { przedsięwzięć uczniowskich }\end{array}$ & $\begin{array}{l}\rightarrow \text { planują działania } \\
\rightarrow \text { racjonalnie gospodarują czasem } \\
\rightarrow \text { docierają do odbiorców (prowadzą działania marketingowe) } \\
\rightarrow \text { formułują zasady dobrej organizacji pracy } \\
\rightarrow \text { monitorują na bieżąco działania } \\
\rightarrow \text { wyjaśniają, dlaczego trzeba na bieżąco monitorować działania } \\
\rightarrow \text { uzasadniają potrzebę korygowania planu } \\
\rightarrow \text { planują alternatywne rozwiązania } \\
\rightarrow \text { uzasadniają potrzebę dokumentowania działań } \\
\rightarrow \text { analizują własne działania i działania innych osób/grup } \\
\rightarrow \text { wyciągają wnioski } \\
\rightarrow \text { omawiają mocne i słabe strony przedsięwzięć } \\
\rightarrow \text { formułują rekomendacje do dalszej pracy }\end{array}$ \\
\hline
\end{tabular}

Źródło: Opracowanie własne.

Zajęcia lekcyjne powinny być tak skonstruowane, by wyposażyć uczniów w umiejętność powiązania różnych dziedzin wiedzy i jej wykorzystania. Taka organizacja procesu nauczania ma pomóc uczniom zrozumieć otaczający świat i prawa nim rządzące. Dlatego należy wyjść od zmiany koncepcji roli nauczyciela. Musi on stać się organizatorem, strategiem i negocjatorem, motywować uczniów i inicjować ich działania. Uczniowie natomiast powinni w wyraźny sposób wpływać na proces uczenia się i stawać się odpowiedzialni za własny rozwój. Istotne jest, by młody człowiek uczył się rozwiązywać autentyczne problemy, które mogą go zainteresować.

Postawione cele mogą zostać osiągnięte dzięki zastosowaniu różnorodnych aktywnych metod uczenia się i nauczania.

\section{Metody i formy ksztalcenia}

Uczniowie powinni pracować metodami aktywnymi, nauczyciel zaś, wprowadzając treści programowe, powinien uczyć jednocześnie umiejętności pracy zespołowej, rozwiązywania konfliktów, planowania pracy, 
odpowiedzialności, rozwijania kreatywnych umiejętności, gromadzenia informacji, ich selekcji; powinien integrować zespół, pozwalać uczniom na własną ekspresję, uczyć zasad prezentacji, samooceny, wyciągania wniosków, a nawet planowania wydatków. $Z$ działaniami tymi nie można czekać, aż uczeń będzie dojrzały, należy kształtować je od najmłodszych lat. Warto też pamiętać, by zaczynać od działań na niewielką skalę, aby uczeń wdrożył się do pracy, poznał swoje możliwości, nauczył się polegać na kolegach i udowodnił, że inni mogą polegać na nim, a także by mógł doświadczać sukcesów i porażek. Tak dobrane metody wydają się najlepszym narzędziem do realizacji spiralnego układu treści kształcenia i celów wychowawczych sformułowanych w programach nauczania.

Zalecane są metody problemowe, służące zrozumieniu i działaniu, np. dyskusje i debaty, odgrywanie ról, scenek, drama, drzewko decyzyjne, gwiazda pytań, gra dydaktyczna, giełda pomysłów, burza mózgów, metoda przypadków, praca z interaktywnymi multimediami, słoneczko, poker kryterialny, metoda projektów.

Nauczyciel, realizując zajęcia, powinien sięgać głównie po formy pracy zbiorowej, by rozwijać umiejętności pracy w grupie, komunikacji i wzajemnego wspierania się w rozwiązywaniu problemów. Indywidualizacja pracy może być stosowana poprzez samodzielne tworzenie tekstów i realizację ćwiczeń interaktywnych, ale przede wszystkim poprzez udział ucznia w projektach, a tym samym realizację przyjętych na siebie zadań i gromadzenie informacji potwierdzających własny rozwój - portfolio.

W pierwszym etapie edukacji proces kształcenia powinien być ukierunkowany na całościowy rozwój dziecka, rozpoznawanie jego możliwości, wspieranie mocnych stron i korygowanie słabszych. Zajęcia powinny być tak skonstruowane, by motywować do poznawania siebie i otoczenia, by gromadzić doświadczenia, eksperymentować. To okres, gdy dzieci są bardzo ciekawe, chcą poznawać świat, są otwarte i pozytywnie nastawione do wszelkich nowości. Ta naturalna ciekawość otaczającego świata wpływa na motywację do uczenia się.

\section{Propozycje rozwiązań praktycznych}

Kształtowanie kompetencji przedsiębiorczych można realizować $w$ trakcie zajęć wychowawczych. Już od pierwszego etapu kształcenia nauczyciel-wychowawca organizuje różnorodne uroczystości. Powtarzającym 
się świętem w części szkół są wigilie. W klasach I-III bardzo często w organizację włączają się rodzice. To bardzo ważne z punktu widzenia dziecka - daje mu poczucie bezpieczeństwa, a także możliwość pochwalenia się swoimi umiejętnościami i osiągnięciami. Ważne, by wychowawca nie oddał całej inicjatywy w ręce rodziców, ale znalazł zadanie, za które odpowiedzialne będą dzieci, np. dekoracja sali. Na pewno choinka ubrana przez rodziców będzie bardziej elegancka, ale wykonanie ozdób świątecznych i zawieszenie ich na choince oraz w sali to na pewno zadanie, które mogą wykonać same dzieci (oczywiście na lekcjach, pod kierunkiem nauczyciela). Dzięki takim zadaniom uczą się odpowiedzialności i współpracy, stają się współodpowiedzialne za uroczystość. Zazwyczaj nauczyciel przygotowuje z dziećmi przedstawienie, by mogły wystąpić przed rodzicami. Tutaj też można część inicjatywy oddać w ręce dzieci. Mogą wybrać teksty i osoby występujące, przygotować dekoracje. W klasach starszych, na drugim etapie edukacji, trzeba ograniczać ingerencję rodziców w organizację uroczystości klasowych i coraz większą inicjatywę przekazywać samym uczniom. Organizacja wspólnych przedsięwzięć klasowych może być najlepszym sposobem na rozwój kluczowych kompetencji. W trakcie realizacji należy przecież podzielić obowiązki, wybrać osobę, która będzie odpowiedzialna za całokształt (lidera), zebrać (a później rozliczyć) fundusze i przede wszystkim wywiązać się z podjętych zobowiązań. Pojawią się więc tutaj zarówno planowanie, poszukiwanie pomysłów, argumentowanie, monitorowanie przedsięwzięcia, jak i gospodarowanie czasem oraz funduszami. W starszych klasach w ramach działań wychowawczych można w ręce uczniów oddać inicjatywę związaną z przygotowaniem wycieczki. Organizacja takiego przedsięwzięcia to już kompletne zadanie, wymagające wykorzystania wielorakich umiejętności i pełnej współpracy grupy.

Ważnym elementem kształtowania umiejętności przedsiębiorczych są projekty. Uczniowie mogą je realizować już w klasach I-III. Początkowo mają one charakter ogólnoklasowy i są całkowicie realizowane w szkole. Uczniowie uczą się, bawią i przygotowują prezentacje, na które zapraszają inne klasy. Ciekawym projektem, realizowanym w jednej ze szkół, były „Kontynenty". W ramach tego zadania uczniowie klas III tworzyli prezentacje dotyczące wylosowanego kontynentu - przygotowywali dekoracje, stroje, wybierali informacje, które później przekazywali kolegom, zapraszając ich do wspólnej zabawy. Realizując ten projekt, nie tylko zdobyli wiedzę przedmiotową, lecz także kształtowali 
umiejętności. Warto również korzystać z gotowych inspiracji, programów dostosowanych do konkretnych etapów edukacji, np. program realizowany przez Fundację Młodzieżowej Przedsiębiorczości „Od grosika do złotówki" wprowadzający do klas II-III edukację finansową.

W starszych klasach projekt jako metoda pracy powinien pojawiać się na konkretnych przedmiotach. Jednak trzeba uważać, by nie było ich zbyt wiele i by nie przerzucić całej odpowiedzialności na rodziców. Dlatego niezbędne są tutaj współpraca wszystkich nauczycieli uczących daną klasę i wspólne uzgadnianie większych działań edukacyjnych. Należy pamiętać o tym, że mimo rejonizacji szkół podstawowych dzieci nie zawsze mają możliwość spotkania się w swoim gronie po lekcjach i wspólnego realizowania zadania. Takie spotkania często uniemożliwia też nadmiar zajęć pozalekcyjnych. W efekcie może dojść do sytuacji, w której rodzice tylko jednego dziecka zrealizują zadanie, a grupa odda je jako wspólny efekt. I tutaj mamy już antyedukację. Kolejny problem polega na częstej rezygnacji nauczycieli z prezentacji osiągnięć, ponieważ skupiają się jedynie na ocenianiu efektu. Tym samym rezygnują z kształcenia wielu niezbędnych umiejętności i właściwie wypaczają założenia metody projektów. Właśnie ten końcowy efekt wymaga największej pracy i pozwala zdobyć najwięcej umiejętności, budzi też ogromne emocje. Uczniowie muszą stanąć przed grupą i pokazać, czego się nauczyli. Jednak nie zawsze musi to być wystąpienie - zamiast niego można zorganizować np. stoiska, przy których zainteresowani dowiedzą się, co uczniowie zrobili, i dzięki temu sami też wiele się nauczą.

\section{Ocenianie}

Ocenianie w szkole podstawowej powinno łączyć elementy merytoryczne z motywacją, ze szczególnym naciskiem na motywację na pierwszym etapie edukacji. Dlatego warto wprowadzić ocenianie kształtujące, które umożliwia przekazanie uczniowi i jego rodzicom informacji o sposobach oraz efektach pracy, postępach i trudnościach (Sterna 2015). Tym samym ocena ułatwi uczniowi zrozumienie celów zajęć i oczekiwanych osiągnięć, a także przyczyni się do przejęcia odpowiedzialności za własną naukę.

W procesie oceniania powinni uczestniczyć uczniowie, dokonując samooceny i oceny pracy grupy, oraz nauczyciel. Ocenie podlega praca ucznia, czyli sam proces uczenia się, a nie tylko jego efekt końcowy. Doceniane będą postępy oraz wysiłki uczniów, szczególnie w zakresie współ- 
pracy i wzajemnej pomocy. W trakcie wykonywania zadań uczniowie mają możliwość zastanowienia się nad własnymi motywacją i sposobem uczenia się. Informacje wynikające z obserwacji, przekazywane na bieżąco, pomogą w budowaniu poczucia własnej wartości. Informacja zwrotna przekazywana uczniowi i jego rodzicom powinna zawierać:

$\rightarrow$ wyszczególnienie i docenienie tych elementów pracy ucznia, które są wykonywane prawidłowo,

$\rightarrow$ zauważenie tego, co wymaga poprawy,

$\rightarrow$ udzielenie wskazówek, jak poprawić pracę,

$\rightarrow$ wskazanie uczniowi kolejnych celów.

Ocenianie pracy ucznia podczas realizacji innowacji jest skorelowane z obowiązującymi w szkole zapisami dotyczącymi oceniania.

Podczas pracy nauczyciel, obserwując działania swoich podopiecznych, gromadzi i analizuje informacje niezbędne do stymulowania aktywności poszczególnych uczniów, a także planowania i organizowania ich działań. Obserwację tę prowadzi, uwzględniając:

$\rightarrow$ samodzielność, umiejętność wyznaczenia celu i określenia zagadnień istotnych dla rozważanego problemu,

$\rightarrow$ sposób współpracy w zespole,

$\rightarrow$ terminowość i odpowiedzialność w wywiązywaniu się z zaplanowanych prac,

$\rightarrow$ umiejętność rozwiązywania pojawiających się problemów,

$\rightarrow$ pracowitość i inicjatywę,

$\rightarrow$ wykorzystanie różnorodnych źródeł informacji,

$\rightarrow$ umiejętność doboru i selekcji informacji,

$\rightarrow$ umiejętność dokonania samooceny adekwatnej do wkładu i efektów pracy.

\section{Wnioski i rekomendacje}

Wyniki w nauce poszczególnych uczniów zależą od nich samych, ale najlepsze efekty osiąga się wówczas, kiedy nauczyciele podchodzą do nauczania z punktu widzenia uczniów. Szkoła to instytucja, która musi iść z duchem czasu, zmieniać się, nie tylko uczyć, lecz także uczyć się. Należy zmienić podejście do edukacji, odejść od encyklopedyzmu, skoncentrować się na działaniu. Głównym zadaniem szkoły, na każdym etapie edukacji, musi być rozwijanie umiejętności. Dlatego należy sięgać po nowoczesne metody, gdyż obecne pokolenie znacznie różni się od 
młodych ludzi z poprzedniej generacji. Dorastali w świecie nowoczesnych technologii, mają więc bardzo wysoką zdolność funkcjonowania w wirtualnym świecie. Realne życie i kontakty interpersonalne zastępują kontaktami w wirtualnym świecie. Przyszły rynek pracy kształtuje się już w szkole, więc od sposobu kształcenia młodych ludzi zależy ich późniejsza sytuacja w życiu zawodowym. 


\section{Bibliografia}

$\rightarrow$ Sterna, D. (red.) (2015), Oceniam, ucząc. Poradnik dla nauczycieli edukacji wczesnoszkolnej, Warszawa: Centrum Edukacji Obywatelskiej.

$\rightarrow$ Moss, C.M., Brookhart, C.M. (2014), Cele uczenia się. Jak pomóc uczniom zrozumieć każdq̨ lekcję, tłum. Weronika Gasperczyk, Warszawa: Centrum Edukacji Obywatelskiej.

$\rightarrow$ Marciniak-Kulka, E., Neyman, O., Wysocka, J. (2017), Wspomaganie szkół w kształtowaniu kompetencji: innowacyjność, kreatywność i praca zespołowa uczniów, Warszawa: Ośrodek Rozwoju Edukacji.

$\rightarrow$ Rozporządzenie Ministra Edukacji Narodowej z dnia 14 lutego 2017 r. w sprawie podstawy programowej wychowania przedszkolnego oraz podstawy programowej kształcenia ogólnego dla szkoły podstawowej, w tym dla uczniów z niepełnosprawnością intelektualną w stopniu umiarkowanym lub znacznym, kształcenia ogólnego dla branżowej szkoły I stopnia, kształcenia ogólnego dla szkoły specjalnej przysposabiającej do pracy oraz kształcenia ogólnego dla szkoły policealnej.

$\rightarrow$ Kompetencje kluczowe w uczeniu się przez całe życie. Europejskie ramy odniesienia (2007), Luksemburg: Urząd Oficjalnych Publikacji Wspólnot Europejskich.

$\rightarrow$ Komisja Europejska/EACEA/Eurydice (2012), Developing Key Competences at School in Europe: Challenges and Opportunities for Policy (Rozwijanie kompetencji kluczowych w szkołach w Europie. Wyzwania i możliwości tworzenia polityki edukacyjnej) Raport Eurydice, Luksemburg: Urząd Publikacji Unii Europejskiej. 